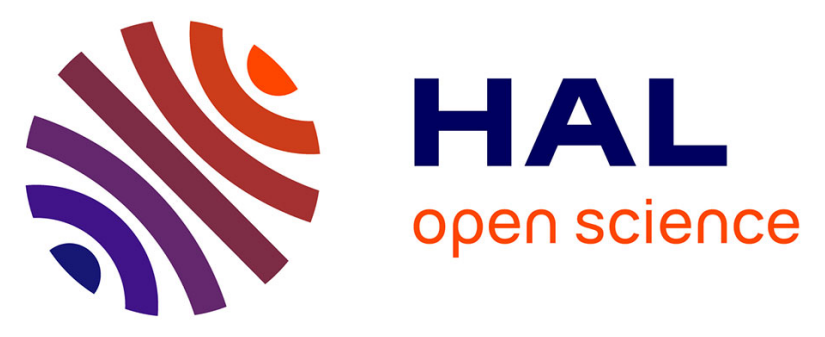

\title{
The Leprosarium of Saint-Thomas d'Aizier: the cementochronological proof of the medieval decline of Hansen disease in Europe?
}

Joël Blondiaux, Stephan Naji, Jean-Pierre Bocquet-Appel, Thomas Colard, Amélie de Broucker, Cécile de Seréville-Niel

\section{To cite this version:}

Joël Blondiaux, Stephan Naji, Jean-Pierre Bocquet-Appel, Thomas Colard, Amélie de Broucker, et al.. The Leprosarium of Saint-Thomas d'Aizier: the cementochronological proof of the medieval decline of Hansen disease in Europe?. International Journal of Paleopathology, 2016, 15, pp.140-151. 10.1016/j.ijpp.2015.02.005 . halshs-01715280

\section{HAL Id: halshs-01715280 \\ https://shs.hal.science/halshs-01715280}

Submitted on 22 Feb 2018

HAL is a multi-disciplinary open access archive for the deposit and dissemination of scientific research documents, whether they are published or not. The documents may come from teaching and research institutions in France or abroad, or from public or private research centers.
L'archive ouverte pluridisciplinaire HAL, est destinée au dépôt et à la diffusion de documents scientifiques de niveau recherche, publiés ou non, émanant des établissements d'enseignement et de recherche français ou étrangers, des laboratoires publics ou privés.

\section{(ㅇ)(1) $\$$}

Distributed under a Creative Commons Attribution - NonCommercial - NoDerivatives 44.0 


\title{
The leprosarium of Saint-Thomas d'Aizier: The cementochronological proof of the medieval decline of Hansen disease in Europe?
}

\author{
Joël Blondiaux ${ }^{\mathrm{a}, *}$, Stephan Naji ${ }^{\mathrm{b}}$, Jean-Pierre Bocquet-Appel ${ }^{\mathrm{c}}$, Thomas Colard ${ }^{\mathrm{d}}$, \\ Amélie de Broucker ${ }^{\mathrm{e}}$, Cécile de Seréville-Niel ${ }^{\mathrm{b}}$ \\ a Centre d'Etudes Palèopathologiques du Nord, 36 rue Jules Ferry, 59127 Walincourt-Selvigny, France \\ b Centre Michel de Bouärd, CNRS, UMR 6273, Université de Caen, Esplanade de la paix, 14032 Caen Cedex, France \\ c CNRS, UPR2147 44, rue de l'Amiral Mouchez, 75014 Paris, France \\ d Lille University, Forensic Taphonomy Unit-Anthropology, Lille Forensic Institute, 59000 Lille, France \\ e Lille University, Forensic Taphonomy Unit-Anthropology, Lille Forensic Institute, 59000 Lille, France
}

\section{A R T I C L E I N F O}

\section{Article history:}

Received 3 July 2013

Received in revised form 17 February 2015

Accepted 18 February 2015

\section{Keywords:}

Leprosy

Survival function

Middle ages

Cementum

France

\begin{abstract}
A B S T R A C T
This study compares the adult survivorship profiles of people interred in the Saint-Thomas d'Aizier leprosarium, estimated by cementochronology, to eight archaeological series in northern France dated from Late Antiquity to the Late Middle Ages, periods of significant visibility for Hansen's disease (leprosy). The goals are to understand the impact of leprosy on various social groups and to explore the cause of leprosy's decline by analyzing male and female fertility. Survival rates differed between medieval leprosy-free sites and the Saint-Thomas d'Aizier leprosarium, although this difference was statistically significant only for the female leprosarium sample. The selective female frailty, a consequence of social exclusion and the collapse of the quality of life, combined with the infertility of lepromatous couples, offer a multi-causal explanation to the end of the expansion and then decline of leprosy in southern and western European countries.
\end{abstract}

(C) 2015 Elsevier Inc. All rights reserved.

\section{Introduction}

Demographic factors related to leprosy in the past have been relatively underexplored, yet the disease is known to impact mortality and fertility. We therefore suspect that changes in demographic parameters played a role in the decline of this disease. Clinical analyses highlight the major role of specific pathologies on mortality and morbidity, such as suicide, tuberculosis (TB), renal insufficiency, and cancer (Tokudome et al., 1981). In addition, the possibility that couples affected by leprosy would have a lower fertility due to male infertility has been raised since the early 20th century (McCoy, 1913). McCoy was the first to discuss the frequency of orchiepididymitis (inflammation of the testicles) in lepromatous patients. The same year, Barbézieux (1913) argued that the decline of leprosy and its disappearance during the 17 th century in France was due to the legal requirement that lepromatous persons and their descendants (i.e., "cagots") marry affected

\footnotetext{
* Corresponding author. Tel.: +33 327827439.

E-mail addresses: jblondiaux@nordnet.fr(J. Blondiaux), stephan.naji@gmail.com (S. Naji), jean-pierre.bocquet-appel@evolhum.cnrs.fr (J.-P. Bocquet-Appel), thomas.colard@free.fr (T. Colard), ameliedebroucker@hotmail.fr (A. de Broucker), cecile.niel@unicaen.fr (C. de Seréville-Niel).
}

partners, in addition to male infertility. More recently, Beiguelman (1967) collected a large demographic dataset on leprosy patients and concluded that since orchiepididymitis is frequent among lepromatous males, many were rendered sterile. However, in the fertile fraction of lepromatous males, fecundity was similar to that of healthy males. Women's fertility, however, seemed to be unaffected, as demonstrated by the comparable spontaneous abortion rates observed between lepromatous and healthy females. Leprosy induced male infertility and a possible increased mortality of males and females due to leprosy and other pathogens should therefore be explored to assess their respective effects on the disease's 17th century decline. One source of historical information is represented by bioarchaeological data. However, the paucity of demographic analyses from archaeological sources, such as the English medieval leprosaria in Chichester and Winchester in England (Magilton et al., 2008; Roffey and Tucker, 2012; Taylor et al., 2013) and Næstved in Denmark (Bennike et al., 2005; MøllerChristensen, 1953) limits our understanding of the demography dynamics of Hansen disease (i.e., leprosy) in Medieval Europe. Without this information, any conclusions about the "decline of leprosy" in Europe attributed to the selective impact of tuberculosis (Donoghue et al., 2005) or to the secondary effects of the 14th century Black Death (Bassukas et al., 2012; Lechat, 2002) appear premature. 
To explore relationship between mortality, fertility, and paleodemography, a precise adult age-at-death estimation method is required. The only available technique that combines accuracy and reliability is cementochronology, usually referred to as the "TCA" count. In the past 30 years, several researchers have developed and applied this technique for human age-at-death estimations by counting the cementum increments of dental roots (Charles et al., 1986; Kagerer and Grupe, 2001; Solheim, 1990; Stott et al., 1982; Wittwer-Backofen et al., 2004). Recent methodological improvements, both for producing histology slides and counting the cementum increments, have resulted in a significant increase in the accuracy and controls for inter/intra-observer count error (Blondiaux et al., 2006; Colard et al., 2015; Gocha and Schutkowski, 2013; Robbins Schug et al., 2012; Wedel, 2007; Wittwer-Backofen, 2012; Wittwer-Backofen et al., 2008). The cementochronology approach is the only method that allows for the direct counting of a growing tissue (cementum) without statistical calibration, Bayesian or otherwise, or the need for a reference population. It is only restrictive in the sense that it requires the presence of one tooth per individual with suitable preservation, a requirement similar to that for any other biological indicator (Naji et al., 2014). Because we now have a tool to estimate the age-at-death of archaeological skeletal series with precision, paleoepidemiologists and paleodemographers have the opportunity to investigate the differential impact of various pathogens on historic and prehistoric series without the impediment of some of the osteological paradox's issues concerning selective mortality (Wood et al., 2002).

The first objective of this study is to compare demographic profiles of skeletons from a French medieval leprosarium to eight archaeological series dated from Late Antiquity to the Late Middle Ages by sex and by age, estimated through cementochronology. These are all from a geographically and politically restricted area of northern France and have been archaeologically and historically characterized in terms of socioeconomic levels. This contextual background is essential to interpret the differences in survivorship and allows us to compare the samples by sex and economic status. In addition, a paleopathological characterization of the skeletons will serve for discussing the evolution and decline of leprosy during the Late Middle Ages.

Therefore, a second objective is to test the hypothesis put forward by Donoghue et al. (2005) that the co-occurrence of tuberculosis and leprosy, associated with depressed socioeconomic factors, increased early mortality in local populations and thus precipitated the decline of leprosy. Since we have identified individuals with potential lesions due to both leprosy and tuberculosis at two sites (Aizier and Arras), we also have the opportunity to directly test the impact of the co-occurrence of $M$. leprae and $M$. tuberculosis versus the impact of TB alone on two distinct archaeological samples.

Using a bioarchaeological approach, that is, using combined historical, archaeological, paleopathological, and demographical data, a third objective will be to discuss the question of male infertility and elevated female mortality within the leprosarium to explore the pathocenoses that may have contributed to the decline of leprosy at the end of the Middle Ages in Europe.

Our fourth and final objective is to consider the proposal that the confinement of various populations in medieval Europe preceded and accompanied the decline of leprosy and might be linked to its disappearance.

\section{Materials and methods}

\subsection{Material}

Nine osteological series (Fig. 1) housed at the Center for Paleopathological Studies (Walincourt-Selvigny, France) were studied.
They represent a total of 1701 adult skeletons dating from Late Antiquity (450 AD) to the Late Middle Ages (1300 AD) (Table 1). These series were selected based on extensive excavations of each site and overall good bone preservation. Because the archaeological context was systematically evaluated for each site, we anticipate no major taphonomic biases and thus consider these series to be representative samples of the regional population. From these skeletons, one permanent tooth, mostly monoradicular and anterior, was sampled from each of 842 adults with observable teeth. Cementochronology was then used to estimate age-at-death and the corresponding samples survivorship curves. The sample of adult individuals with identified leprosy comes from the medieval leprosarium of Saint-Thomas d'Aizier(STA; Haute-Normandy, France), dated from 1150 to $1550 \mathrm{AD}$ (Fig. 2). The rest of the series represents the samples without observed leprous lesions.

\subsubsection{Saint-Thomas d'Aizier leprosarium}

The total STA sample is comprised of 186 (88.3\%) adults and only 24 (11.6\%) subadults identified in situ, either as individual burials or as commingled remains. Eight were buried in the same aisle of the chapel, five are in the north cemetery, two are in the southern sector, and one teenager was in a single tomb located at the chevet of the building. It is noteworthy that the graves of the youngest were grouped in close proximity along the north wall of the nave or under the eaves (sub stillicidio). They probably benefited from a privileged location in the cemetery, while the burials of older children, in the most northeastern area, appear more dispersed among the adult burials. Overall, the excavation and taphonomic study of the cemetery did not reveal any burials with more than one individual. Sex estimation based on the morphology and size of the pelvis (Bruzek, 2002; Buikstra and Ubelaker, 1994) was possible for 125 individuals, including two older teenagers. At Aizier, 70 males are present along with 55 females (sex ratio=1.27). A male predominance was observed for individuals buried inside the chapel (12 males for 3 females).

\subsubsection{Comparative sites}

Eight sites, totaling 1519 adults, make up the comparative sample. Archaeological contextual information was used to estimate the settlement type (rural, urban, and religious) and to assess the social status (wealthy or poor) (Table 1 ).

1. The urban site of the "Îlot de la Boucherie" in Amiens (France) was excavated between 2006 and 2007. This $5200 \mathrm{~m}^{2}$ site revealed the presence of a vast cemetery around an amphitheater and contained 277 burials. The systematic study of the skeletons and associated artifacts offered a detailed picture of a significant sample of the Amiens population during Late Antiquity (290-395 AD). Available information includes overall health assessments as well as the social and possible ethnic composition of the predominantly young male workers and millet eaters of Germanic origin (Binet, 2012a,b; Blondiaux, 2012).

2. The Arras-Prefecture site is strictly contemporary with STA (1200-1300 AD) and is composed of lower-class individuals buried around the chevet of the medieval cathedral of Arras (Jacques et al., 1988). This urban cemetery yielded 81 skeletons, including 65 complete and well-preserved adults. A cluster of five burials contained five skeletons with bone and joint TB (Blondiaux et al., 1992).

3. "Les Rues des Vignes" is a Merovingian cemetery (480-680 AD), with 269 burials having been excavated from 1980 to 1982 (Blondiaux, 1986). Sex diagnosis has been confirmed on $64.5 \%$ of the adult sample (62 males and 69 females). At least three cases of bone and joint TB have been recorded. 


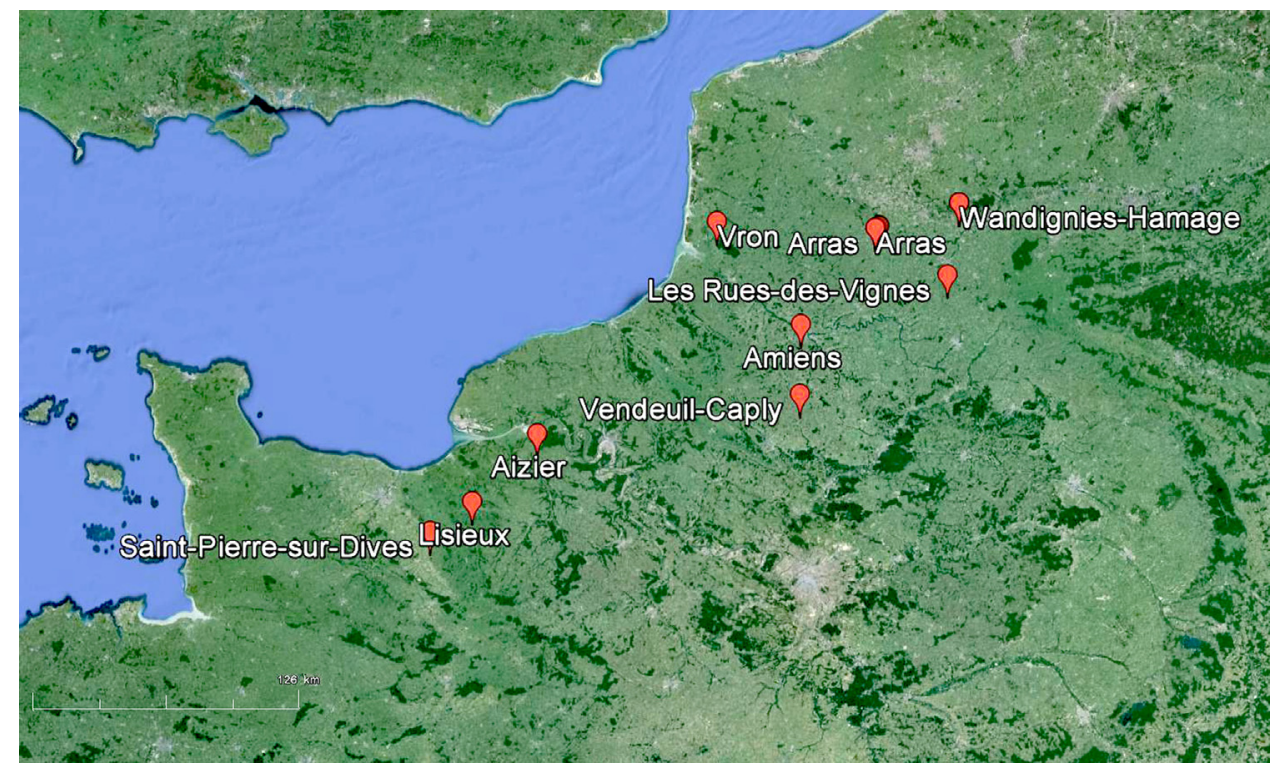

Fig. 1. Location of the town of Aizier (Eure) in Haute-Normandy, France.

4. The site of Lisieux-Michelet (866 burials), dated from 280 to 750 $A D$, was part of a wealthy Gallo-Roman city with an important military garrison (Paillard et al., 2006).

5. Twenty burials were excavated from the choir of the abbey church of Saint-Pierre-sur-Dives (Normandy) in 1997. These upper-class burials date from the 12 th and 13 th centuries $A D$ and consisted of 19 male skeletons and only one female (Alduc-Le Bagousse et al., 2004).

6. The site of the "Marmousets" at Vendeuil-Caply (France) has been archaeologically interpreted as a rural site, even though its cemetery is located near vast cultural and religious buildings (vicus) (Piton, 2009). Two contiguous burial areas represent two chronological phases. The earliest area (178 burials, 250-380 AD) only yielded a few grave goods. Within this area, there is a distinct cluster of individuals with lesions of probable tubercular origin. The more recent area (45 burials, 500-600 AD) was replete with grave goods. Within this second area, there was a cluster of 7 individuals with bone lesions suggestive of leprosy (acro-osteolysis, cortical resorption, tarsal destruction)

7. Vron was excavated from 1971 to 1975 and is dated from 308 to $700 \mathrm{AD}$ (Seillier, 2006). The initial component of the site is a Germanic settlement on the Litus Saxonicum. The site revealed 219 individuals, among which half were positively diagnosed as males (41), females (36), and subadults (38). No signs of TB have been observed.

8. Wandignies-Hamage is a female monastic community dated from the 7th to 11th centuries $\mathrm{AD}$ (Louis and Blondiaux, 2009). A clear segregation of sex and social origins is marked within the cemeteries, both inside and outside the community buildings.

Table 1

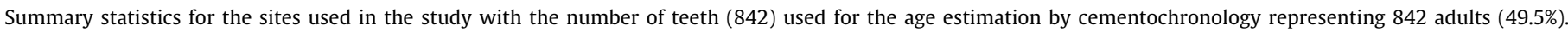
$\mathrm{N}=$ number, $\mathrm{LA}=$ late antiquity, $\mathrm{LMA}=$ late middle ages, EMA = early middle ages

\begin{tabular}{|c|c|c|c|c|c|c|c|c|}
\hline Sites & Skeleton (N) & Adult (N) & Sub-adult (N) & Tooth (TCA) (N) & Periods & Context & Social status & Sources \\
\hline Amiens Boucherie & 277 & 148 & 129 & 147 & LA 3rd-4th c. & Urban, workers & Poor & Binet $(2012 a, b)$ \\
\hline Arras Préfecture & 81 & 65 & 16 & 30 & LMA $10-12$ th c. & Urban & Poor & $\begin{array}{l}\text { Jacques et al. } \\
\text { (1988) }\end{array}$ \\
\hline Les Rues des Vignes & 269 & 203 & 66 & 127 & EMA 6-7th c. & Rural & Rich & $\begin{array}{l}\text { Blondiaux } \\
\text { (1986) }\end{array}$ \\
\hline Lisieux Michelet 1 & 648 & 458 & 190 & 94 & LA 4th c. & Urban & Rich & $\begin{array}{l}\text { Paillard et al. } \\
(2006)\end{array}$ \\
\hline Lisieux Michelet 2 & 218 & 155 & 63 & 35 & EMA 6-7th c. & Urban & Rich & $\begin{array}{l}\text { Paillard et al. } \\
\text { (2006) }\end{array}$ \\
\hline Saint Pierre sur Dives & 20 & 20 & 0 & 17 & LMA $12-13$ th c. & Rural & Rich & $\begin{array}{l}\text { Alduc-Le } \\
\text { Bagousse et al. } \\
\text { (2004) }\end{array}$ \\
\hline Saint Thomas d'Aizier & 206 & 182 & 24 & 63 & LMA $12-15$ th & Leprosarium & Poor & $\begin{array}{l}\text { Niel et al. } \\
(2007)\end{array}$ \\
\hline Vendeuil-Caply 1 & 178 & 115 & 63 & 90 & LA 3rd-4th c. & Rural & Poor & Piton (2009) \\
\hline Vendeuil-Caply 2 & 45 & 35 & 10 & 30 & EMA 5-6th c. & Rural & Poor & Piton (2009) \\
\hline Vron 1 & 116 & 92 & 24 & 46 & LA 4th c. & Rural, migrants & Poor & Seillier (2006) \\
\hline Vron 2 & 47 & 41 & 6 & 39 & EMA 5 c. & Rural & Rich & Seillier (2006) \\
\hline Vron 3 & 56 & 48 & 8 & 37 & EMA 6-7th c. & Rural & Poor & Seillier (2006) \\
\hline Wandignies-Hamage & 167 & 139 & 28 & 87 & EMA 6-9th c. & Nunnery & Rich & $\begin{array}{l}\text { Louis and } \\
\text { Blondiaux } \\
\text { (2009) }\end{array}$ \\
\hline Total & 2328 & 1701 & 627 & 842 & & & & \\
\hline
\end{tabular}




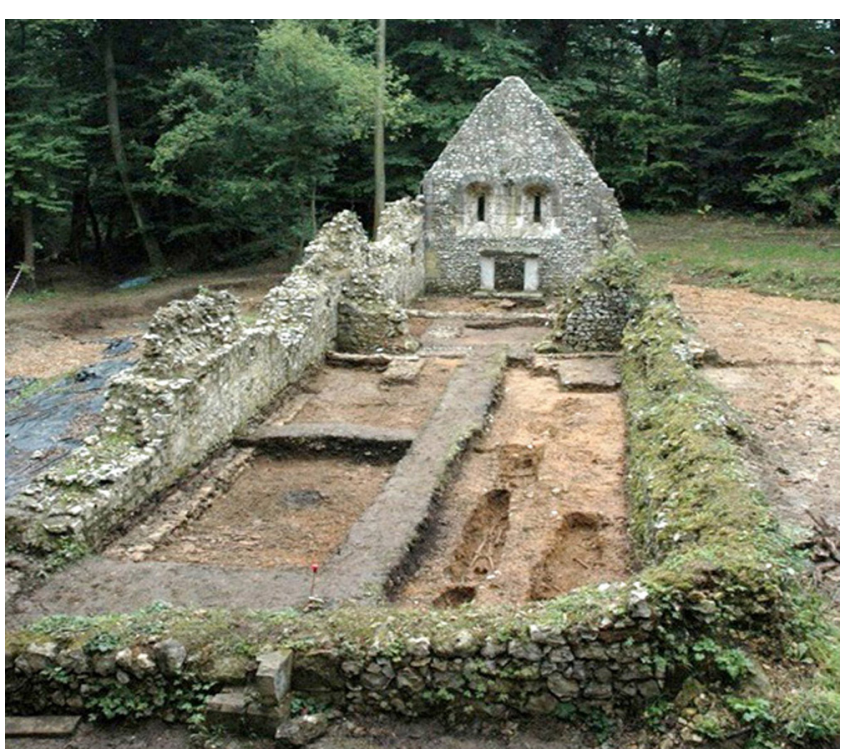

Fig. 2. Archaeological site of the medieval leprosarium of Saint-Thomas d'Aizier (photo by. C. de Seréville-Niel).

\subsection{Methods}

Adult median age-at-death and survivorship curves estimated by cementochronology are compared to assess the mortality differences among the archaeological samples and subsamples. The sex estimations for the skeletons used the Bruzek (2002) method or the Buikstra and Ubelaker (1994) standards, depending on the skeletal parts available for observation.

\subsubsection{Individual adult-age estimation: Cementochronology}

Age estimations were made by cementochronology. Cementum is the interface between the periodontal ligament and the root of the tooth, and it serves for the attachment of the tooth in the alveolar bone (Hillson, 1996). This histological method, developed in animal biology (Linhart, 1973) and later applied to human remains (Charles et al., 1986; Stott et al., 1982), and requires observations of tooth roots cross-sections for alternating dark and clear banding increments, which are visible when thin sections are microscopically viewed under direct transmitted light (Wittwer-Backofen et al., 2004). As described by Blondiaux and colleagues (Blondiaux et al., 2006), sections were obtained from monoradicular teeth (mostly premolars) and embedded in an epoxy resin (Araldite Brot). The resulting block was trimmed to reduce cutting time. Eight transverse sections of $80-100 \mu \mathrm{m}$ were then obtained for each tooth using a micrometric low-speed diamond saw (Buehler Isomet). Unpolished sections were mounted using Canadian balsam. Each field was observed in normal light at $200 \times$ magnification on a Nikon Labophot microscope equipped with a digital camera. Twenty microscopic fields per tooth were selected and photographed. The images were then displayed on a computer, and the cementum increments were counted utilizing Adobe Photoshop software. The modal average counts added to the average date of tooth eruption (Liversidge et al., 1998) were recorded on an automated spreadsheet, which included the standard error specific to the reference sample (software by B. Bertrand, Archaeological Service CAD, Douai, France).

To control for biases due to alveolar bone destruction in Hansen's disease, Magniez (2012) compared the frequency of dental conditions of the STA adults with those of the comparative rural, urban, rich and poor populations. The STA oral health did not seem to differ from the rural and poor samples, with the exception of teeth exposed by alveolar resorption due to rhinomaxillary syndrome (Andersen and Manchester, 1992). Therefore, the anterior maxillary teeth (when preserved) were not used for cementochronology at STA. Most of the premolars did not exhibit additional microscopic cementolysis relative to the other archaeological teeth used in this study. This assessment is of importance when dealing with the ante mortem erosion and post mortem diagenesis of tooth cementum.

\subsubsection{Survival functions}

The statistical survivorship function applied to the age at death data was the Kaplan-Meier technique (Kaplan and Meier, 1958; SPSS software). Kaplan-Meier-estimated survivorship functions are a series of horizontal steps of decreasing size that allow an approach to the actual survival in the population when a sufficiently large sample is used. The value of the survivorship function between successive samples is considered constant. If no truncation or censoring is reached, the Kaplan-Meier estimate is equivalent to the empirical distribution function.

The logrank-test (Mantel-Cox) statistic compares the estimates of the hazard functions for two groups at each observed event. It is constructed by first computing the observed and expected number of events in one of the groups for each observed event, and then adding these to obtain an overall summary across all time points where there is an event. The survivorship curves have been traced according to the standardized survivorship (cumulative) commonly used for the study of survival rates, and the conventional $p$-value of 0.05 was used to reject the null hypothesis of there being no difference between two groups.

\subsubsection{Pathology}

The diagnosis of leprous lesions uses Andersen, Manchester and colleagues' criteria for rhinomaxillary syndrome, tibiofibular periosteal lesions, infective lesions of the metatarsals and metacarpals, concentric diaphyseal lesions of the metatarsals and phalanges, manual phalangeal grooves, and cup and peg interphalangeal joint lesions (Andersen and Manchester, 1992; Andersen et al., 1994). Of the 43 skeletons with facial bones preserved in STA, $34(76.4 \%)$ present at least two criteria of rhinomaxillary syndrome (Fig. 3), thus having one of the highest proportions of lepromatous cases studied in France thus far (Colard et al., 2011). Regarding the periosteal reaction of the lower limbs, a radiographic study associated with microscopic verification was applied to 35 pairs of tibiae and fibulae. Of these, $85 \%$ (31 pairs) had radiographically visible appositions of new bone of variable thicknesses and extension, while only 55\% were macroscopically visible. Of the four pairs "free" of macroscopic or radiographic lesions, two showed remodeled apposition on microscopic sections (Ruffin et al., 2011). The thickness and extent of periosteal apposition was positively correlated with age, but rhinomaxillary syndrome was not (Ruffin et al. 2011).

Lesions characteristic of disseminated TB were included in our samples to examine leprosy and TB covariance. These lesions include lumbar and thoracic vertebral cavitations, remodeled periosteal appositions of the pleural surfaces of the ribs, hypertrophic pulmonary osteopathy and bone and joint lesions. Even if some of these lesions are non-specific, we believe that it is valid to use them as expressions of TB with necessary restrictions (Nicklisch et al., 2012). Seven skeletons exhibited remodeled periosteal appositions of the pleural surfaces of the ribs, possibly related to TB. Research linking such ribs and atypical spinal lesions to TB is inconclusive, however, possibly because there are few cases confirmed with ancient DNA(aDNA) and mycolipids analyses, but also because there is a lack of precise studies of radiographs, anatomic pathology, or pre-antibiotic clinically confirmed cases (Baker, 1999; Haas et al., 2000; Pfeiffer, 1984; Santos and Roberts, 2006; Spekker et al., 2012). 


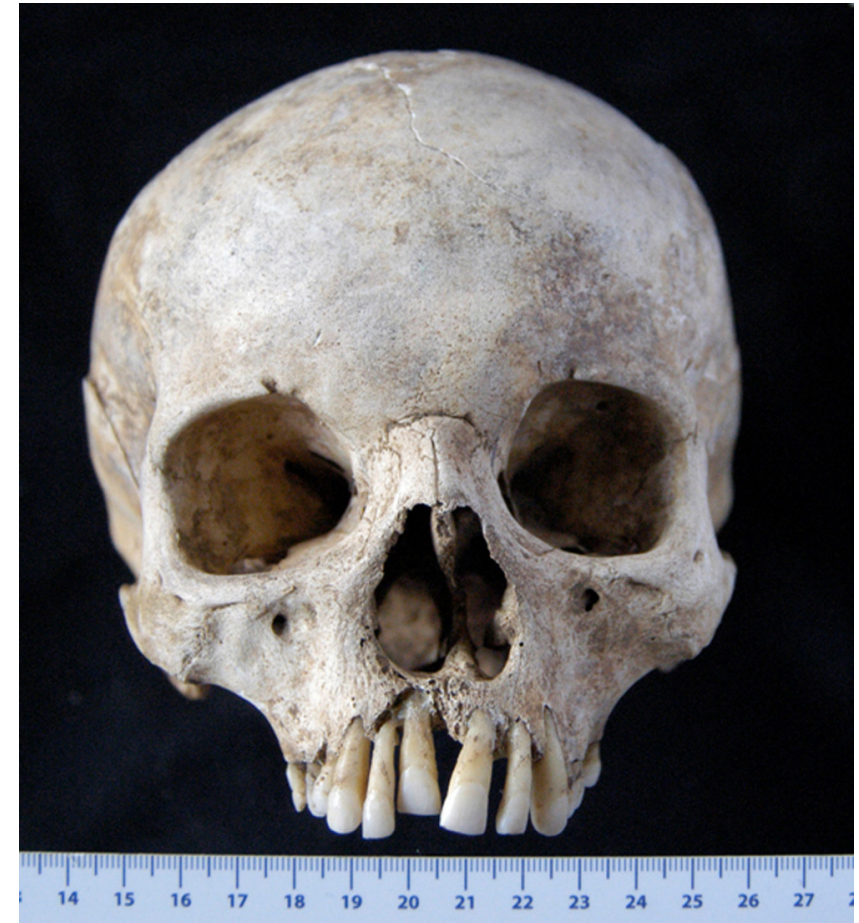

Fig. 3. Saint-Thomas d'Aizier (\# 904), male, aged $47.3 \pm 1.8 \mathrm{yrs}$, frontal view of the rhino-maxillary syndrome.

A spine sample (STA 642) with lumbar and thoracic vertebral cavitations (Fig. 4) was associated with cribra femoris and cribra orbitalia. Vertebral cavitations are present as smooth-walled circumferential resorptives lesions of thoracic and lumbar vertebral bodies (Baker, 1999). The extensive and irregular pitting is associated to superficial remodeling and porosities. Cribra femoris or Allen's fossa, is a lesion formed by atrophy of the cortical bone located symmetrically on the anterior surface of the femoral neck reminiscent of an inflammatory response (Finnegan, 1978). Cribra orbitalia were identified as clusters of five or more micro-sieves located on the ceiling of the orbits. Additional descriptions and scoring for the lesion's degree and activity followed Buikstra and Ubelaker (1994).

A radiographic study of a 19-year-old subadult vertebral bodies (STA 642) clearly revealed centered translucent zones surrounded by dense and mostly irregular areas. These lesions are different from the residual sinus venous grooves commonly seen in juveniles in the central anterior portion of the vertebral body (Keats and Anderson, 2012) and described as Hahn cleft and transverse growth recovery stress lines (Freyschmidt et al., 2002). The comparison of the "cavitations" and topography of the vertebral walls of this individual to descriptions published from autopsy samples (Ménard, 1888) and to a picture of tubercular caries (Fig. 5) suggests that this adolescent could combine both Hansen's disease and an early stage of "tubercular" caries. In his publication, Ménard, 1888 classified this lesion as a superficial and early stage of tuberculosis, very different from Pott's disease, which would be a more localized, destructive, and chronic form of TB. This description is later used by Sorrel and Dejerine-Sorrel (1932) as "diffuse and superficial", and often lethal in children and adolescents. Freyschmidt et al. (2002) describe this multiple vertebral tuberculosis as superficial anterior tuberculosis spondylitis. This case could illustrate the coexistence of the two mycobacteria infections, M. leprae and M. tuberculosis, and confirm the deleterious impact of TB in an individual carrying the stigma of lepromatous leprosy. A bone sample of STA 642 taken by Mark Spigelman has been submitted to aDNA analysis to Helen Donoghue's laboratory in London.

\section{Results}

\subsection{Adult survival by site and sex}

There is a definite hierarchy of survivorship levels based on the social background of each sample as estimated from its archaeological context. Among the female samples (Fig. 6 and Table 2), the
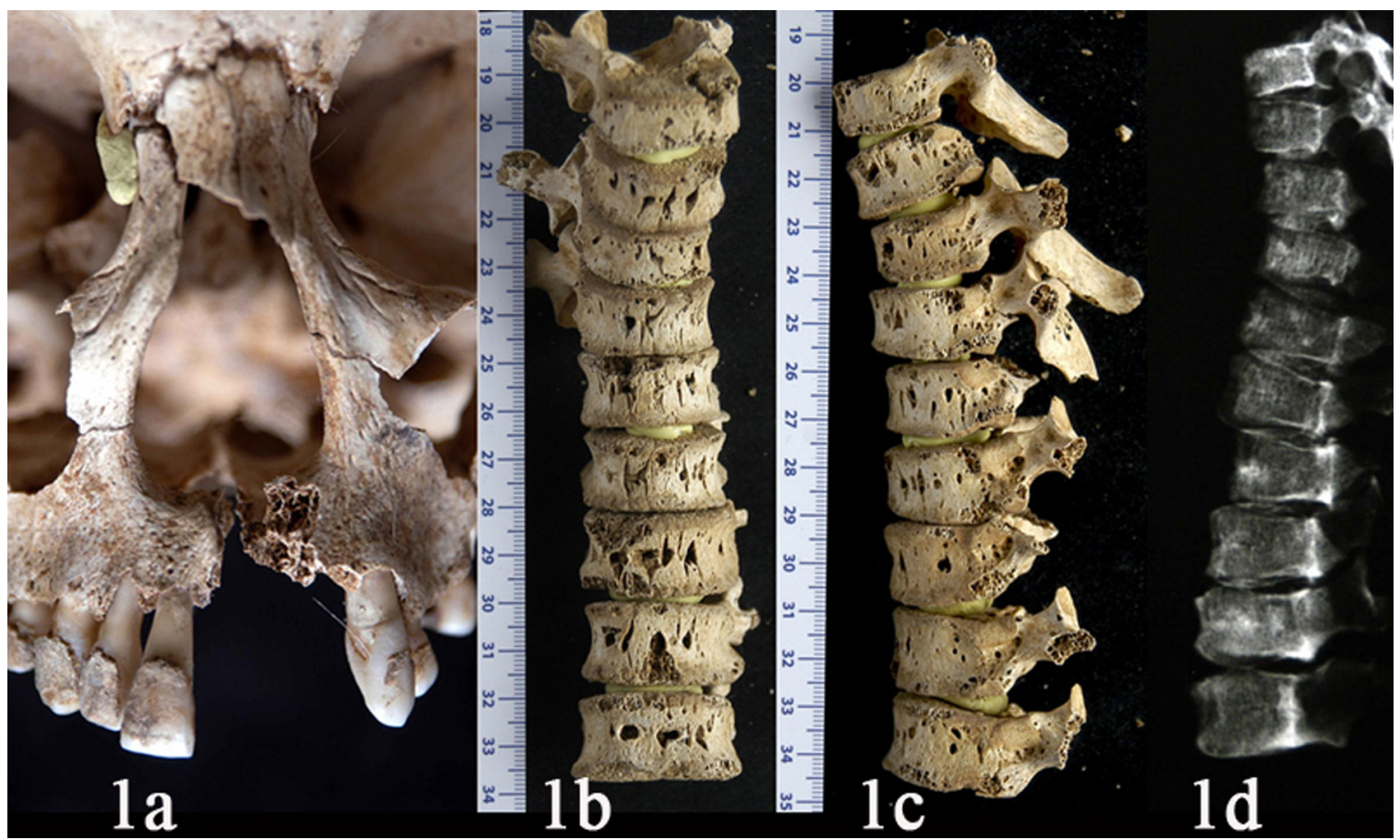

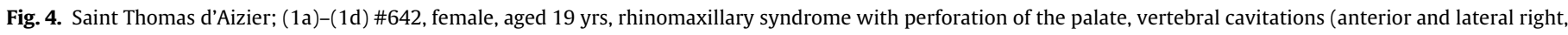
with radiography lateral right).

Please cite this article in press as: Blondiaux, J., et al., The leprosarium of Saint-Thomas d'Aizier: The cementochronological proof of the medieval decline of Hansen disease in Europe? Int. J. Paleopathol. (2015), http://dx.doi.org/10.1016/j.ijpp.2015.02.005 


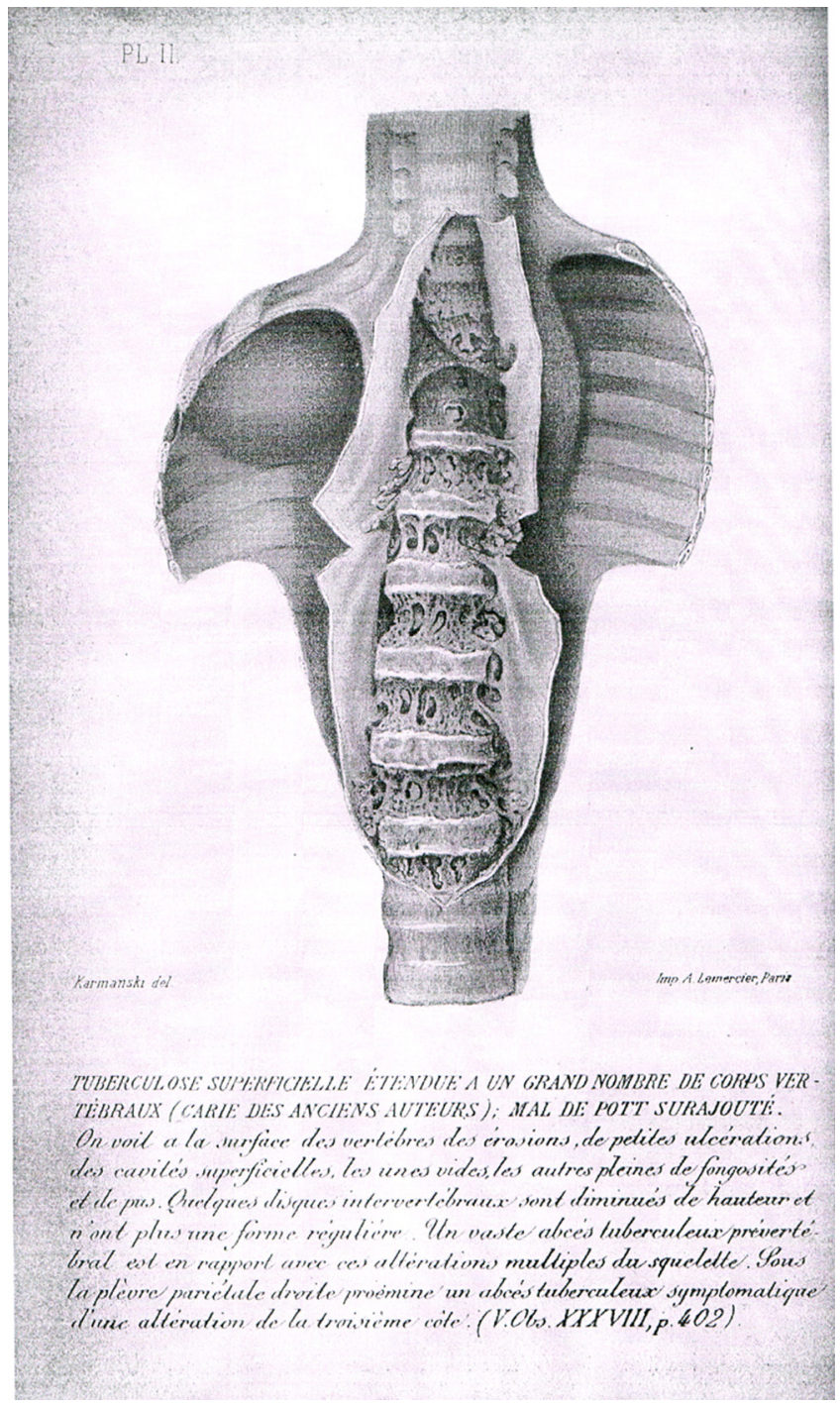

Fig. 5. Copy of Plate 11 from Victor Ménard's book (1888), drawn by Karmanski. The picture shows vertebral cavitations in a five year-old child who died from tuberculosis. The associated comment states: "we can see on the surface of the vertebrae erosions, small ulcerations, superficial cavities, some empty, some full of fongosity and pus $[\ldots]$. Under the right parietal pleura there is a prominent tubercular abscess symptomatic of an alteration of the third rib." This superficial form described by Ménard is visibly more advanced than for STA-482.

highest survivorship curve is inferred for the aristocratic nuns from the monastery of Hamage. The middle survivorship curves are from Vron (rural) and two urban female series in Amiens. The aristocratic religious site has the highest mean age-at-death (MAD) and the leprosarium the lowest, while the three rural secular cemeteries are intermediate. However, all the sites except Hamage present similar survival patterns during the first decade of adult life.

The survivorship curves for the eight male adult series (Fig. 7 and Table 3 ) follow a similar pattern. The lowest survival at all ages

Table 2

Summary statistics for adult female survival curves by site. MAD = mean age-atdeath; $\mathrm{CI}=$ confidence interval $\pm 95 \%$.

\begin{tabular}{lllll}
\hline Females & Teeth $(\mathrm{N})$ & MAD & $\mathrm{CI}-95 \%$ & $\mathrm{CI}+95 \%$ \\
\hline St-Thomas d'Aizier & 25 & 31.9 & 26.9 & 36.9 \\
Amiens & 55 & 34.7 & 31.7 & 37.7 \\
Vron & 43 & 40.1 & 33.8 & 46.4 \\
Lisieux & 31 & 46.8 & 33.7 & 49.5 \\
Hamage & 58 & 57.1 & 53.9 & 60.3 \\
\hline
\end{tabular}

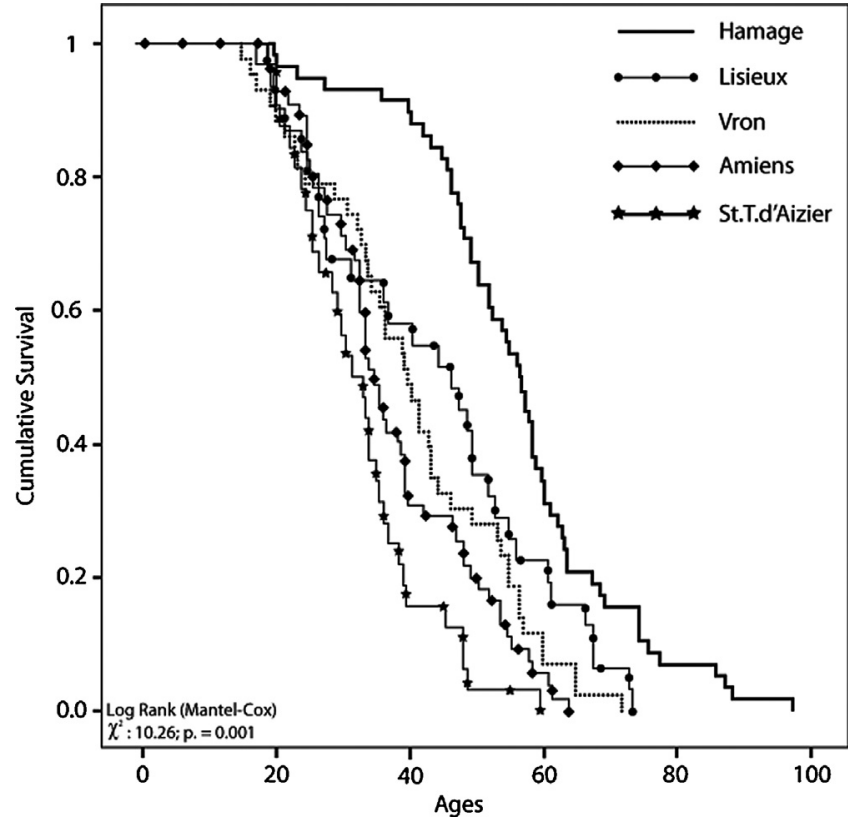

Fig. 6. Survivorship curves of 5 adult female groups.

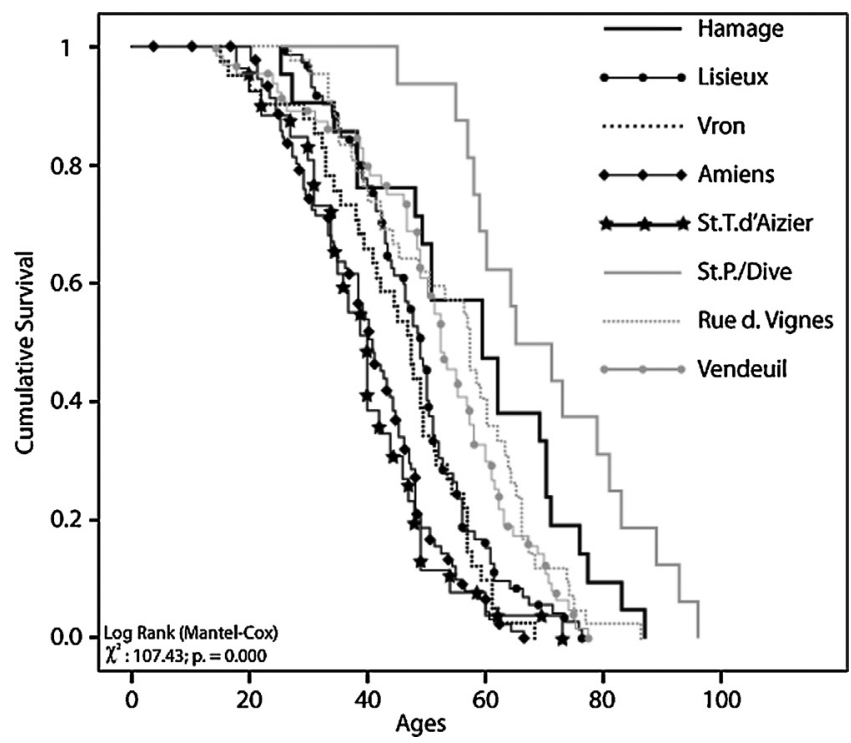

Fig. 7. Survivorship curves of 8 adult male groups.

before 50 is from STA leprosarium, while the highest survivorship involves the two aristocratic church burial sites (St Pierre-sur-Dive and Hamage), with MADs of 65 and 59.4 years, respectively. The other six rural and urban male series follow various survivorship patterns, depending on their socioeconomic levels, similar to the

Table 3

Summary statistics for adult male survival curves by site. MAD = mean age-at-death $\mathrm{CI}=$ confidence interval $\pm 95 \%$

\begin{tabular}{lllll}
\hline Males & Teeth $(\mathrm{N})$ & $\mathrm{MAD}$ & $\mathrm{CI}-95 \%$ & $\mathrm{CI}+95 \%$ \\
\hline St-Thomas d'Aizier & 26 & 39 & 35 & 43 \\
Amiens & 92 & 40.9 & 37.5 & 50.3 \\
Vron & 42 & 47.3 & 43.7 & 50.9 \\
Lisieux & 72 & 49 & 46 & 51.9 \\
Hamage & 21 & 59.4 & 43.1 & 75.7 \\
Vendeuil & 64 & 52.6 & 49.1 & 56.1 \\
Rue des Vignes & 42 & 57.3 & 51.7 & 62.9 \\
St Pierre sur Dive & 16 & 65 & 51.3 & 78.7 \\
\hline
\end{tabular}


Table 4

Summary statistics for adult male and female survival curves. MAD = mean age-atdeath; $\mathrm{CI}=$ confidence interval $\pm 95 \%$.

\begin{tabular}{lllll}
\hline & Teeth $(\mathrm{N})$ & MAD & CI $-95 \%$ & $\mathrm{CI}+95 \%$ \\
\hline Amiens male & 92 & 39 & 36.6 & 44 \\
Amiens female & 55 & 33.8 & 30.7 & 36.8 \\
Vron male & 42 & 46.8 & 42.6 & 51 \\
Vron female & 43 & 40.1 & 34.8 & 45.4 \\
STA male & 26 & 39.3 & 30.55 & 48.1 \\
STA female & 25 & 29.4 & 24.48 & 34.32 \\
STA indeterminate & 12 & 38.9 & 32.3 & 45.5 \\
STA total & 63 & 35.3 & 32.6 & 38 \\
Arras male & 16 & 38 & 34.21 & 41.38 \\
Arras female & 13 & 38 & 32.13 & 43.07 \\
Arras total & 29 & 38 & 34.9 & 41.3 \\
\hline
\end{tabular}

trend observed for the female curves. It is noteworthy that the Amiens profile is close to that of Saint-Thomas d'Aizier, even though its MAD is higher. Amiens is hypothetically the "poorest" of the sites for survivorship and social background after STA.

For both sexes, the lowest survival function is for the STA medieval leprosarium, with MADs of 31.9 (Table 2) and 39 (Table 3 ) for the females and males, respectively, which are both statistically significant $(p<0.001)$.

\subsection{Adult survival by sex (pooled)}

In our larger series (Amiens, Vron, and STA; Table 4), we observe that female survival from 20 to 50 years follows the same lower curve as the males, even though only STA reached statistical significance (Figs. 8-10). Following this gap in the survival curves, all three samples show considerable overlap. The undetermined sex component of STA (Fig. 10) does not affect the difference between male and female survival and its significance.

\subsection{Adult survival and the co-occurrence of tuberculosis and leprosy}

Both the STA (with leprosy) and Arras-Prefecture (without leprosy) sites include individuals consistent with a possible diagnosis

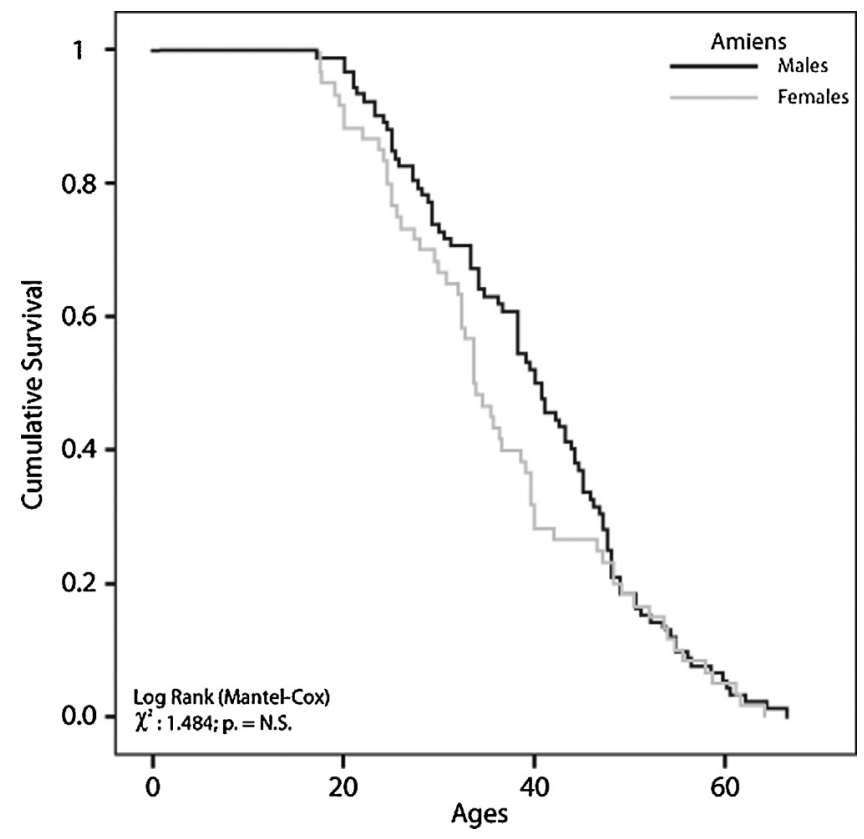

Fig. 8. Amiens 4 th century $\operatorname{AD}(N=155)$.

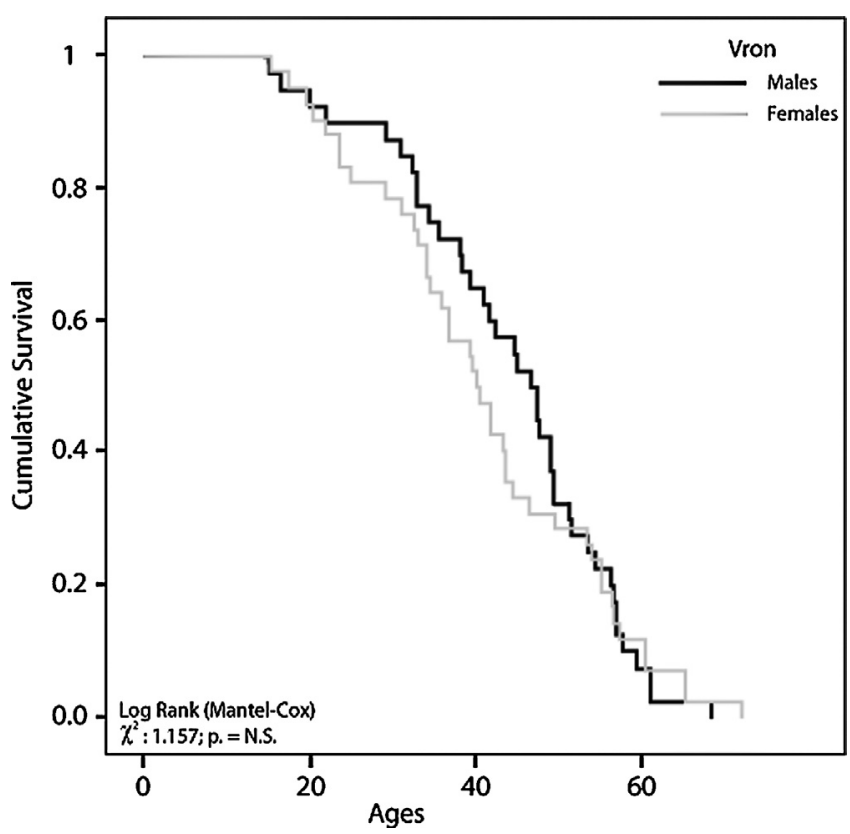

Fig. 9. Vron 4-7th centuries $\mathrm{AD}(N=134)$.

of TB: bone and joint lesions (STA, $n=1$; Arras, $n=3$ ) and periosteal appositions on the visceral rib surfaces (STA, $n=7$; Arras, $n=2$ ). The comparison between their survival curves offered no statistically significant differences (Fig. 11 and Table 4). Consistent with the results from the leprosarium, the survival rate of the females from STA was significantly reduced in comparison to their male counterparts and the Arras sample (Fig. 12 and Table 4).

\section{Discussion}

\subsection{The mortality of adult females}

Applying cementochronology to a large archaeological sample to estimate survivorship curves provides unique opportunities to explore the impact of pathology on human groups. The

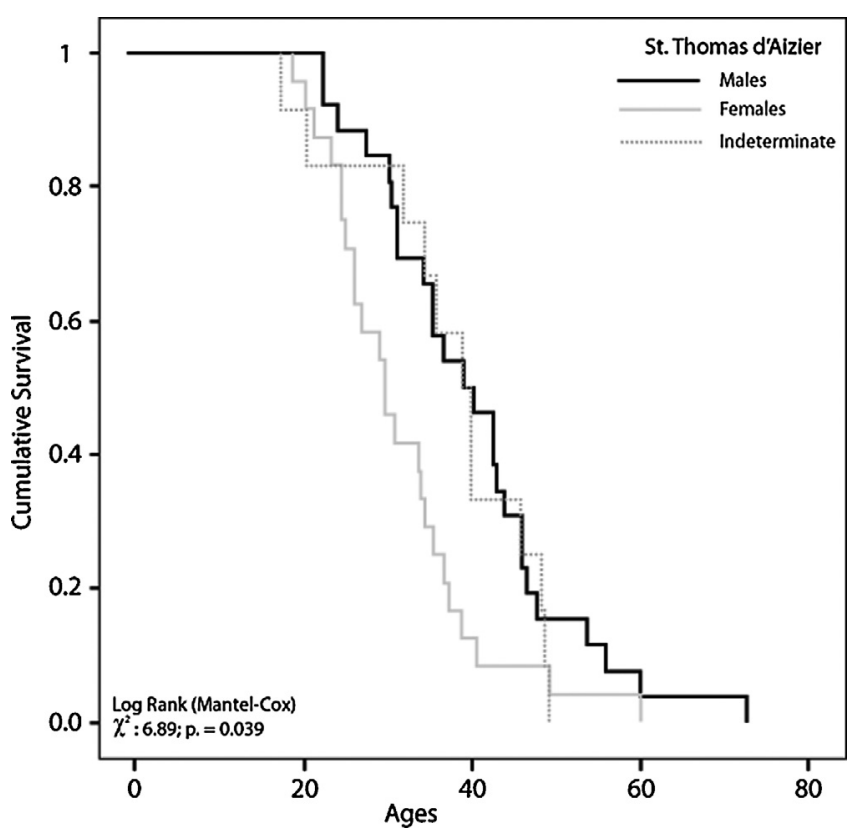

Fig. 10. Saint-Thomas d'Aizier, Survivorship curve by sex $(N=63)$. 


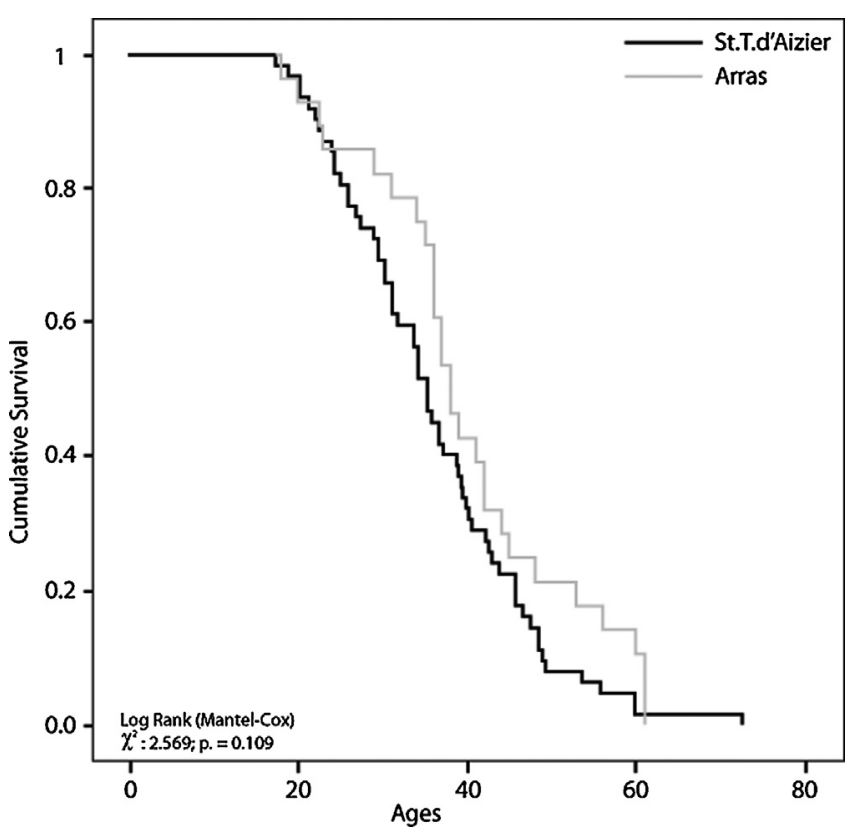

Fig. 11. Saint-Thomas adults versus Arras-Préfecture adults.

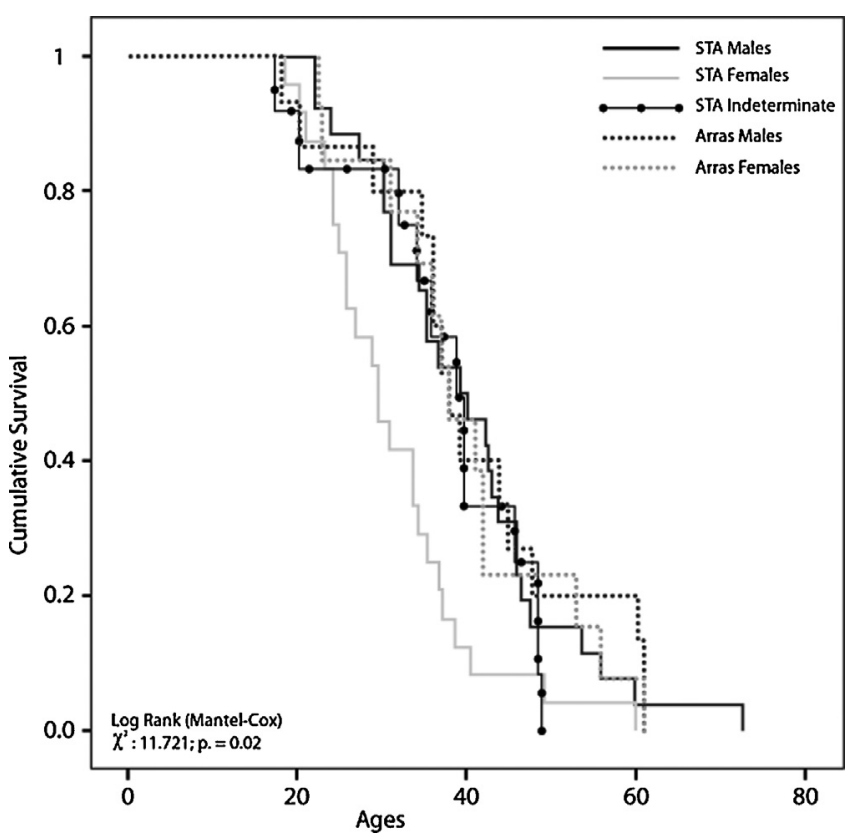

Fig. 12. Survivorship of Saint-Thomas d'Aizier females and males versus Arras females and males.

survivorship curves obtained in the STA leprosarium first suggest a higher mortality for both sexes compared to the samples buried in other cemeteries. STA specifically suggests an increased mortality of the females affected by leprosy. How can we explain this pattern?

Recent clinical studies on cohorts of patients with leprosy (Table 5) have revealed specific causes of mortality, tuberculosis

\section{Table 5}

Summary of modern studies on leprosaria.

\begin{tabular}{llc}
\hline Source & Location & Patient $(N)$ \\
\hline Powell and Swan (1955) & Carville (LA, USA) & 50 \\
Kolonel and Hirohata (1977) & Hawai, (HI, USA) & 1123 \\
Tokudome et al. (1981) & Japan & 2383 \\
Glaziou et al. (1993) & French Polynesia & 673 \\
\hline
\end{tabular}

and cancer, in particular, that could lead to a decrease in life expectancy and partially explain the increased mortality pattern for the females in STA. Powell and Swan (1955) reported a 20\% mortality rate from TB and 18\% from neoplasms, while Glaziou et al. (1993) observed a $13 \%$ mortality rate directly from TB. Other researchers have specifically reported significantly higher mortality among lepromatous females from cancers of the cervix and esophagus as well as from suicides (Kolonel and Hirohata, 1977; Tokudome et al., 1981). Finally, a third major cause of death reported among patients with leprosy in two modern samples is renal insufficiency, possibly as a consequence of chronic urinary infections (Powell and Swan, 1955; Tokudome et al., 1981).

Donoghue et al. (2005) more recently suggested that the immunological changes found in multi-bacillary leprosy, in association with the socioeconomic impact on those suffering from the disease, led to an increased mortality from tuberculosis and therefore, to the historical decline in leprosy. Thus, it is legitimate to look for evidence of TB or cancer, among other diseases, in lepromatous archaeological samples to assess their potential impact on mortality, especially on that of females.

However, there appears to be no significant impact of $M$. tuberculosis to explain the female increased mortality in the STA sample. Among the comorbidities in the individuals exhumed from STA, the one case of possible bone and joint tuberculosis, along with the seven cases of periosteal appositions of the pleural surfaces of the ribs, suggest that TB was endemic. They involve four women aged 19 to 34 years and four men aged 29 to 73 years. It is clearly not possible to project definitive conclusions from such a small sample regarding the impact of TB on differential mortality of both sexes. Taking into account a proportionate number of possible tuberculosis cases in the Arras sample $(n=5)$, we cannot conclude that the mortality patterns are comparable in both locations. Similarly, the absence of pathologically visible neoplasms in the osteological series is inconclusive as to their potential effect on lepromatous mortalities. Finally, regarding the presence and impact of renal insufficiency in the STA sample, we are currently using a microscopic examination of cortical bone to evaluate its potential prevalence. Illustrative of these issues, a round concretion was discovered in the pelvic cavity of a 46 year-old male (\#STA 659). X-ray diffraction and infrared spectrometry revealed a concentric mineral structure with a central cavity characteristic of a vesical calculus (Aufderheide et al. (1998).

As Donoghue et al. (2005) have suggested, analyzing leprosaria for aDNA, and particularly the lipid markers of M. tuberculosis, may make it possible to estimating the prevalence of the disease in people buried in leprosaria and therefore the role of TB in these institutions' decline and closure. Finally, female mortality should be explored by considering maternal mortality and the precarious status of women in this highly hierarchical society, where female marginalization, food deprivation, and stricter reclusion were common (Bériac, 1988, 1984). Some of the factors implicated in the modern studies cited above, such as the suicide rate, may be relevant. Presently, the comparative analysis of STA to the northern French samples has revealed that tuberculosis was present, even though it appears to have played a secondary role as a cofactor for the lepromatous mortality rate.

\subsection{Infertility and maternal mortality}

Because STA is considered to include many individuals with leprosy, the low proportion of immature skeletons poses questions (juvenility index: $5-14 \mathrm{yrs} / 20+\mathrm{yrs}=0.103 ; 15 P 5$ ratio $=5-19 \mathrm{yrs} / 5+$ yrs = 0.119) (Bocquet-Appel, 2008; Bocquet-Appel et al., 2008). The absence of child burials cannot be attributed to taphonomic processes, especially when compared to other secular sites (Table 1). The overall preservation of subadult skeletons was comparable, 


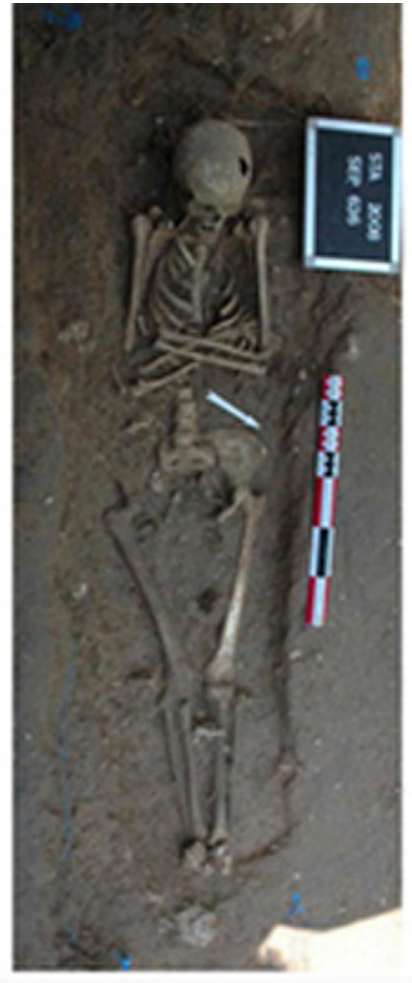

B

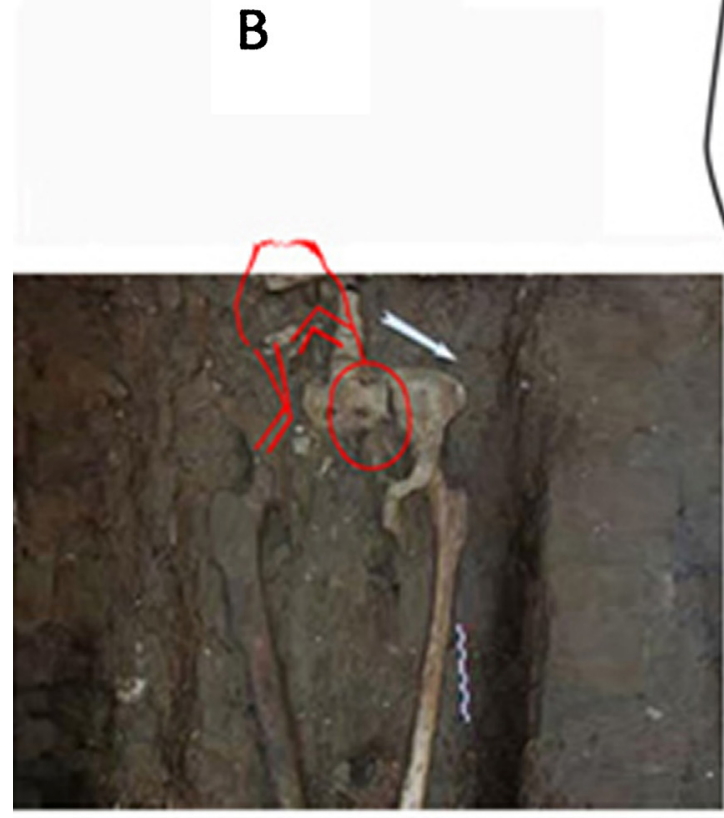

C
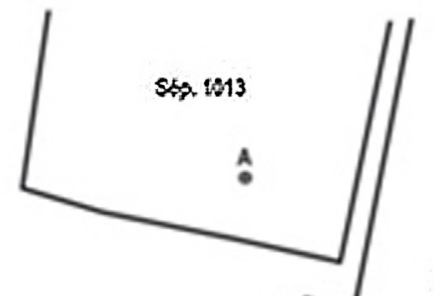

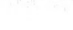

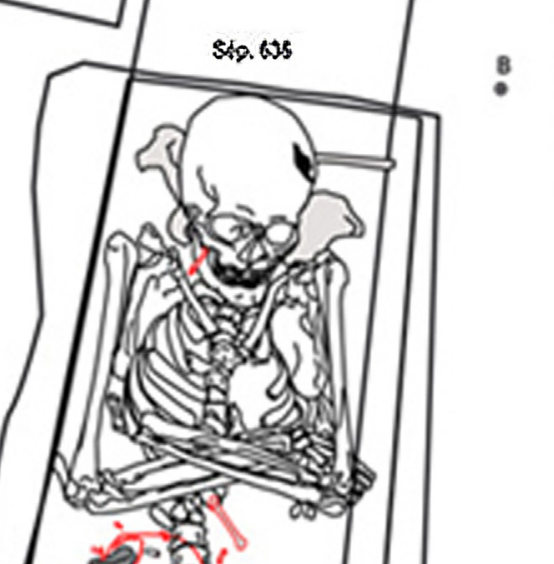

?

$\sin \sin$
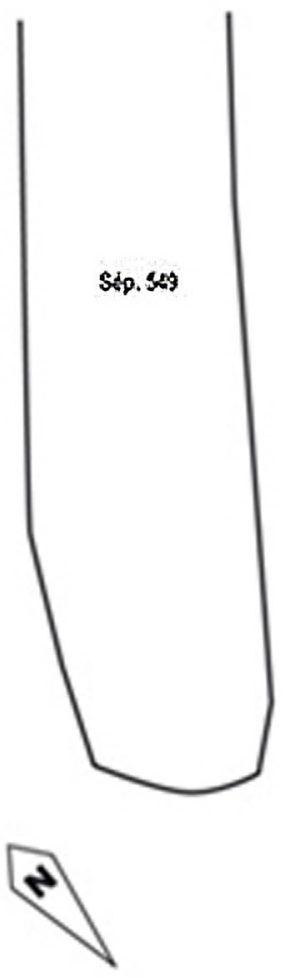

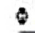

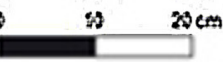

\section{Lezend:}
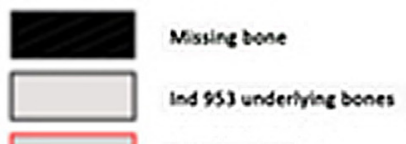

int aseb foetal boes

Elint

Aterted borkt timats

Revered Doriat timizs

Excavosen timits

Novesent Buriat timits

Markers

:
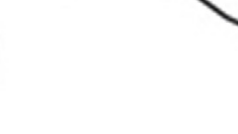

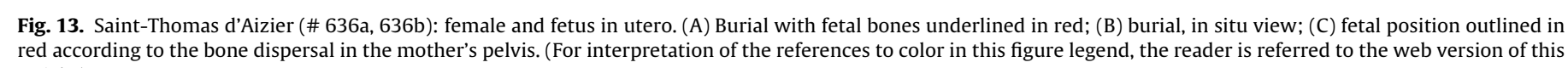
article.)

and no empty graves were identified. Another hypothesis that could explain the absence of children could be that the children of male, females and couples hosted in the leprosarium were removed from their parents early and ultimately pursued their life elsewhere (Bériac, 1988). There were no specific or only sketchily mentioned regulations on child exclusion and expulsion, family status, betrothal, marriage, divorce and sex segregation. Although such explanations have been suggested in few medieval texts, their strict application is uncertain (Brenner, 2007). One fetus and three neonates' remains suggest of active sexual life within the 
resident community at STA and elsewhere (Lewis, 2002). Therefore, the scarcity of subadult burials is the possible real picture of the overall infertility within the leprosarium's inmates.

Increased female mortality may be implicated in the general infertility of reclusive couples, or it could be a direct consequence of maternal mortality. This may be illustrated by one burial of a young lepromatous woman with her at-term fetus in utero, which was free of visible pathology (Fig. 13).

Earlier studies convincingly highlighted the impact of leprosy on male infertility as opposed to normal fertility in female patients with leprosy (Beiguelman, 1967). This was probably true in favorable socioeconomic conditions, which was not the case at STA, where isolation and a low income would have been particularly harmful (Brenner, 2007). Maternal mortality would have certainly exacerbated the decline in fertility of this small community. All of these reasons could explain the relatively low number of immature samples buried at STA.

\subsection{The decline of leprosy}

After the theory of cross-immunization between $M$. tuberculosis and M. leprae raised, long ago by Chaussinand (1944) and Manchester (1984), questioned since then by Wilbur et al. (2002), the hypothesis of Donoghue et al. (2005) implicating tuberculosis in the decline of endemic leprosy is attractive. However, many authors have claimed that the simultaneous development of enhanced immunity against leprosy due to the selective effect that the Black Death could have played a role in the rapid disappearance of Hansen's disease during the 14th and 15th centuries AD (Bassukas et al., 2012; Lechat, 2002).

These are some of the many alternative hypothesized causes for the decline of leprosy in Europe (e.g., low-fertility, social exclusion, and low income associated with leprosy). However, the results of our research suggest an association between higher mortality rates and reduced fertility that may have contributed as well, since we know that, despite the absence of congenital forms, the main route of transmission occurs by droplet infection within households (Moet et al., 2006; Rao et al., 1975).

The impact of complex social and political factors on individual health, as assessed through non-specific indicators of the quality of life, has been demonstrated in modern populations (Audureau et al., 2013). Significant deleterious effects on outcomes including mortality, morbidity and health-related behaviors was observed when individuals were suddenly deprived of work, social interaction and autonomy (Audureau et al., 2013). Examples of such conditions include forcing patients to use their own chests as coffins, sharing single unhealthy timber cabins or dormitory, and living from alms (Niel and Truc, 2009; Niel et al., 2007). Local conditions leading to an overall decreased quality of life and low survival of patients, added to low fertility, surely heavily implicate either the direct impact of diseases on life expectancy or on fertility, and undoubtedly accelerated the inmates demise and the closure of the institution.

\section{Conclusion}

The first objective of this study was to compare demographic profiles of a French medieval leprosarium to eight archaeological series dated from Late Antiquity to the Late Middle Ages, estimated through cementochronology. The results clearly defined a social hierarchy of survivorship levels with skeletons showing signs of leprosy systematically associated with the highest mortality and female's mortality systematically higher than males.

The second objective tested the hypothesis that the cooccurrence of tuberculosis and leprosy increased early mortality in local populations and thus precipitated the decline of leprosy.
Conclusions indicate that the impact of Hansen's disease is indeed perceptible at STA, but other unassessed important factors may have affected the morbidity of this population. Among other possible causes, we found that tuberculosis and chronic urinary infection, even though diagnosed at STA, probably only played a secondary role as a cofactor for the lepromatous mortality rate.

The third objective was to discuss the question of male infertility and elevated female mortality within the leprosarium to explore the pathocenoses that may have contributed to the decline of leprosy at the end of the Middle Ages in Europe. Evidence from the STA leprosarium seem to favor increased maternal and female mortality combined to lepromatous male infertility as the main cause for the decline of leprosy in 17th century Europe.

Our final objective considered the proposal that the confinement of various populations in medieval Europe preceded and accompanied the decline and disappearance of leprosy. The demographic impact of the low quality of life for families with Hansen's disease in these institutions after the 14th clearly played a catalytic context in which the role of pathocenoses such as the Great Plague and endemic TB lead to the decline and disappearance of leprosy. This complex dynamic between social environment and pathocenoses should therefore be meticulously explore to refine our comprehension of leprosy evolution at the end of the Middle Age.

\section{Acknowledgements}

The authors thank Jane Buikstra and three anonymous reviewers who provided comments that greatly improved this manuscript, as well as the help of the American Manuscript Editors. Thanks also go to Marie-Cécile Truc, Raphaëlle Lefebvre, Damien Jeanne and the archaeologists of the Groupe Archéologique du Val de Seine and the Institut National de Recherches Archéologiques Préventives. We are also grateful to Helen Donoghue and Mark Spigelman for their assistance and responsibility of the paleomicrobiological study of STA material. The first author also pays tribute to those affected by leprosy met, from 1973 to 1977 , during weekly clinics on the banks of the Hooghly in Howrah, during monthly clinics on roadsides of Santal Pargana (Bihar), to people of the leprosarium of Chandraghona (Chittagong Hill Tracts) and to two patients diagnosed with leprosy at the Thana Health Center of Shariakandi (Bogra District).

\section{Appendix A. Supplementary data}

Supplementary data associated with this article can be found, in the online version, at doi:10.1016/j.ijpp.2015.02.005.

\section{References}

Alduc-Le Bagousse, A., Blondiaux, J., Desloges, J., Maneuvrier, C., 2004. Les sépultures d'un sanctuaire bénédictin normand: le choeur de l'abbatiale de Saint-Pierresur-Dives. In: Inhumations et Édifices Religieux Au Moyen Âge Entre Loire et Seine, Tables Rondes Du CRAHAM. Publications du CRAHM, Caen, pp. 181-206.

Andersen, J.G., Manchester, K., 1992. The rhinomaxillary syndrome in leprosy: a clinical, radiological and palaeopathological study. Int. J. Osteoarchaeol. 2, 121-129.

Andersen, J.G., Manchester, K., Roberts, C., 1994. Septic bone changes in leprosy: a clinical, radiological and palaeopathological review. Int. J. Osteoarchaeol. 4 21-30.

Audureau, E., Rican, S., Coste, J., 2013. From deindustrialization to individual healthrelated quality of life: multilevel evidence of contextual predictors, mediators and modulators across French regions, 2003. Health Place 22, 140-152.

Aufderheide, A.C., Rodriguez-Martin, C., Langjoen, O.M., 1998. Urinary diseases. In: The Cambridge Encyclopedia of Human Paleopathology. Cambridge University Press, Cambridge, pp. 284-286.

Baker, B.J., 1999. In: Palfi, G., Dutour, O., Deak, J., Hutas, I. (Eds.), Tuberculosis Past and Present. Golden Book and Tuberculosis Foundation, Budapest/Szeged, pp. 301-307.

Bassukas, I.D., Gaitanis, G., Hundeiker, M., 2012. Leprosy and the natural selection for psoriasis. Med. Hypotheses 78, 183-190.

Beiguelman, B., 1967. Leprosy and genetics. A review of past research with remarks concerning future investigations. Bull. World Health Organ. 37, 461-476. 
Bennike, P., Lewis, M.E., Schutkowski, H., Valentin, F., 2005. Comparison of child morbidity in two contrasting medieval cemeteries from Denmark. Am. J. Phys. Anthropol. 128, 734-746.

Bériac, F., 1984. La peur de la lèpre. In: L'Histoire., pp. 56-61.

Bériac, F., 1988. Histoire des lépreux au Moyen age. Une société d'exclus, Imago. ed. Imago, Paris.

Binet, E., 2012a. Présentation générale. In: Binet, E. (Ed.), Amiens, Îlot de La Boucherie, Rapport Final d'Opération. INRAP, Amiens, pp. 7-28.

Binet, E., 2012b. La nécropole du Bas-Empire. In: Binet, E. (Ed.), Amiens, Îlot de La Boucherie. Rapport Final d'Opération, Amiens, pp. 267-332.

Blondiaux, J., 1986. Tentative de reconstitution paléodémographique d'une population mérovingienne du Nord de la Gaule: la nécropole de les rue des Vignes (Nord). Bulletins et Mémoires de la Société d'Anthropologie de Paris 3, série XIV, BMSAP, Corlet Ediiteurs, Condé-sur-Noireau, pp. 163-176.

Blondiaux, J., 2012. Rapport anthropologique et paléopathologique. In: Binet, E. (Ed.), Amiens, Îlot de La Boucherie, Rapport Final d'Opération. INRAP, Amiens

Blondiaux, J., Baud, C.-A., Boscher-Barré, N., Dardenne, C., Deschamps, N., Trocellier, P. Buchet, L., 1992. Trace elements in palaeopathology: quantitative analysis of a case of hypertrophic osteoartropathy by Instrumental Neutron Activation Analysis. Int. J. Osteoarchaeol. 2, 241-244.

Blondiaux, J., Gabart, N., Alduc-Le Bagousse, A., Niel, C., Tyler, E., 2006. Relevance of cement annulations to paleopathology. Paleopathol. Newsl. 135, 4-13.

Bocquet-Appel, J.-P., 2008. La paléodémographie: 99. In: 99\% de l'histoire démographique des hommes. Errance, Paris.

Bocquet-Appel, J.-P., Naji, S., Bandy, M., 2008. Demographic and health changes during the transition to agriculture in North America. In: Bocquet-Appel, J.-P. (Ed.) Recent Advances in Palaeodemography: Data, Techniques, Patterns. Springer Dordrecht, pp. 277-292.

Brenner, E., 2007. The leper house of Mont-aux-Malades, Rouen. In: Tabuteau, B. (Ed.), Étude Des Lépreux et Des Léproseries Au Moyen Âge Dans Le Nord de La France: Histoire, Archéologie, Patrimoine. Centre d'Archéologie et d'Histoire Médiévales des Établissements Religieux, Amiens, pp. 219-246.

Bruzek, J., 2002. A method for visual determination of sex, using the human hip bone. Am. J. Phys. Anthropol. 117, 157-168.

Buikstra, J.E., Ubelaker, D.H., 1994. Standards for Data Collection from Human Skeletal Remains: Proceedings of a Seminar at the Field Museum of Natural History. Organized by Jonathan Haas, Research Seminar Series No. 44, Arkansas Archeological Survey, Fayetteville, Ark.

Charles, D.K., Condon, K., Cheverud, J.M., Buikstra, J.E., 1986. Cementum annulation and age determination in Homo sapiens. I. Tooth variability and observer error Am. J. Phys. Anthropol. 71, 311-320.

Chaussinand, R., 1944. Tuberculose et lèpre, maladies antagonists. Eviction de la lèpre par la tuberculose. Revue Médicale Française d"Extrême Orient 22, 677-685.

Colard, T., Bertrand, B., Naji, S., Delannoy, Y., Bécart, A., 2015. Toward the adoption of cementochronology in forensic context. Int. J. Legal Med., http://dx.doi.org/10. 1007/s00414-015-1172-8.

Colard, T., Blondiaux, J., Demondion, X., Alduc-Le Bagousse, A., Niel, C., 2011. Evolution of skeletal lesions severity in leprosy. In: Presented at the Presented at the 18th European Meeting of the Paleopathology Association. Supplement to the Paleopathology Newsletter, Vienna, p. 115.

Donoghue, H.D., Marcsik, A., Matheson, C., Vernon, K., Nuorala, E., Molto, J.E., Greenblatt, C.L., Spigelman, M., 2005. Co-infection of Mycobacterium tuberculosis and Mycobacterium leprae in human archaeological samples: a possible explanation for the historical decline of leprosy. Proc. Biol. Sci. 272, 389-394.

Finnegan, M., 1978. Non-metric variation of the infracranial skeleton. J. Anat. 125, 23-37.

Freyschmidt, J., Brossmann, J., Wiens, J., 2002. Koehler/Zimmer's Borderlands of Normal and Early Pathological Findings in Skeletal Radiography, fifth ed. Thieme Medical Publishers, Stuttgart, New York, NY.

Glaziou, P., Cartel, J.L., Moulia-Pelat, J.P., Ngoc, L.N., Chanteau, S., Plichart, R., Grosset, J.H., 1993. Tuberculosis in leprosy patients detected between 1902 and 1991 in French Polynesia. Int. J. Lepr. Other Mycobact. Dis. 61, 199-204.

Gocha, T.P., Schutkowski, H., 2013. Tooth cementum annulation for estimation of age-at-death in thermally altered remains. J. Forensic Sci. 58, S151-S155.

Haas, C.J., Zink, A., Molńar, E., Szeimies, U., Reischl, U., Marcsik, A., Ardagna, Y., Dutour, O., Pálfi, G., Nerlich, A.G., 2000. Molecular evidence for different stages of tuberculosis in ancient bone samples from Hungary. Am. J. Phys. Anthropol. 113, 293-304

Hillson, S., 1996. Dental Anthropology. Cambridge University Press, Cambridge.

Jacques, A., Bougard, P., Hilaire, Y.M., Nolibos, A., 1988. Histoire d'Arras. Editions Des Beffrois, Dunkerque

Kagerer, P., Grupe, G., 2001. Age-at-death diagnosis and determination of life history parameters by incremental lines in human dental cementum as an identification aid. Forensic Sci. Int. 118, 75-82.

Kaplan, E.L., Meier, P., 1958. Nonparametric estimation from incomplete observations. J. Am. Stat. Assoc. 53, 457.

Keats, T.E., Anderson, M.W., 2012. Atlas of Normal Roentgen Variants That May Simulate Disease, ninth ed. Saunders, Philadelphia, PA.

Kolonel, L.N., Hirohata, T., 1977. Leprosy and cancer: a retrospective cohort study in Hawaii. J. Natl. Cancer Inst. 58, 1577-1581.

Lechat, M.F., 2002. The palaeoepidemiology of leprosy: an overview. In: Roberts, C.A., Lewis, M., Manchester, K. (Eds.), Past and Present of Leprosy: Archaeological, Historical, Paleopathological and Clinical Approaches: Proceedings of the International Congress on the Evolution and Paleoepidemiology of the
Infectious Diseases 3 (ICEPID), University of Bradford, 26th-31st July 1999, BAR International Series. Archaeopress, Oxford, pp. 157-162.

Lewis, M.E., 2002. Infant and childhood leprosy. In: Roberts, C.A., Lewis, M. Manchester, K. (Eds.), Past and Present of Leprosy: Archaeological, Historical, Paleopathological and Clinical Approaches: Proceedings of the International Congress on the Evolution and Paleoepidemiology of the Infectious Diseases 3 (ICEPID), University of Bradford, 26th-31st July 1999, BAR International Series. Archaeopress, Oxford, pp. 163-169.

Linhart, S.B., 1973. Age determination and occurrence of incremental growth lines in the dental cementum of the common vampire bat (Desmodus rotundus). J. Mammal. 54, 493-496.

Liversidge, H.M., Herdeg, B., Rösing, F.W., 1998. Dental age estimation of non-adults. A review of methods and principles. In: Springer (Ed.), Dental Anthropology: Fundamentals, Limits and Prospects. Verlaag, Heidelberg, pp. 419-442.

Louis, E., Blondiaux, J., 2009. L’abbaye mérovingienne et carolingienne de Hamage (Nord). VIe, mort et sépulture dans une communauté monastique féminine. In: Alduc-Le Bagousse, A. (Ed.), Inhumations de prestige ou prestige de l'inhumation? Expressions du pouvoir dans l'au-delà, Tables rondes du CRAHM. CRAHM, Caen, pp. 291-323.

Magilton, J., Lee, F., Boylston, A. (Eds.), 2008. Lepers Outside the Gate: Excavations at the Cemetery of the Hospital of St. James and St. Mary Magdalene, Chichester Chicester Excavations: CBA Research Report 158. Council for British Archaeology, York, England.

Magniez, A., 2012. Étude paléopathologique du syndrome rhino-maxillaire et de l'état bucco-dentaire d'une population lépreuse medieval. Université Lille 2, Lille (Doctorat).

Manchester, K., 1984. Tuberculosis and leprosy in antiquity: an interpretation. Med. Hist. 28 (2), 162-173.

McCoy, G.W., 1913. Studies upon leprosy. Public Health Bull. 62, 23.

Ménard, V., 1888. Tuberculose vertébrale. Lasselin et Houzeau, Paris.

Moet, F.J., Pahan, D., Schuring, R.P., Oskam, L., Richardus, J.H., 2006. Physical distance genetic relationship, age, and leprosy classification are independent risk factors for leprosy in contacts of patients with leprosy. J. Infect. Dis. 193, 346-353.

Møller-Christensen, V., 1953. Ten lepers from Naestved in Denmark; a study of skeletons from a medieval Danish leper hospital. Danish Science Press, Copenhagen [Tr. from the Danish].

Naji, S., Colard, T., Blondiaux, J., Bertrand, B., d' Incau, E., Bocquet-Appel, J.-P., 2014. Cementochronology, to cut or not to cut? Int. J. Paleopathol., http://dx.doi org/10.1016/j.ijpp.2014.05.003.

Nicklisch, N., Maixner, F., Ganslmeier, R., Friederich, S., Dresely, V., Meller, H., Zink, A., Alt, K.W., 2012. Rib lesions in skeletons from early neolithic sites in Central Germany: on the trail of tuberculosis at the onset of agriculture. Am. J. Phys. Anthropol. 149, 391-404.

Niel, C., Truc, M.-C., 2009. Aizier (Eure) Chapelle Saint-Thomas. Fouille programmée d'une léproserie médiévale. Centre Michel de Bouard, CRAHAM, UMR 6273 CNRS-Université Caen Basse Normandie and Service Régional de l'Archéologie -DRAC de Ba\&sse Normandie, Caen (Rapport Archéologique)

Niel, C., Truc, M.-C., Penna, B., 2007. La Chapelle Saint-Thomas d'Aizier (27). Premiers résultats de six années de fouille programmée. In: Tabuteau, B. (Ed.), Étude Des Lépreux et Des Léproseries Au Moyen Âge Dans Le Nord de La France: Histoire, Archéologie, Patrimoine. Centre d'Archéologie et d'Histoire Médiévales des Établissements Religieux, Caen, pp. 47-108.

Paillard, D. Buchet, L., Alduc-Le Bagousse, A, 2006. Nombre d'inhumés, nombre d'habitants. Estimations archéologiques et anthropologiques: Lisieux, Calvados, IVe s. de notre ère. In: Buchet, L., Dauphin, C., Séguy, I. (Eds.), La Paléodémographie. Mémoire D’os, Mémoire D’hommes (actes Des $8 \mathrm{e}$ Journées Anthropologiques de Valbonne, 5-7 Juin 2003). APDCA, Antibes, pp. 209-223.

Pfeiffer, S., 1984. Paleopathology in an Iroquoian Ossuary, with special reference to tuberculosis. Am. J. Phys. Anthropol, 65, 181-189.

Piton, D., 2009. Vendeuil-Caply (Oise)-Les Marmousets: une nécropole de la fin du Bas-Empire. Archéologie en Picardie.

Powell, C.S., Swan, L.L., 1955. Leprosy: pathologic changes observed in fifty consecutive necropsies. Am. J. Pathol. 31, 1131-1147.

Rao, P.S., Karat, A.B., Kaliaperumal, V.G., Karat, S., 1975. Transmission of leprosy within households. Int. J. Leprosy Other Mycobact. Dis. 43, 45-54

Robbins Schug, G., Brandt, E.T., Lukacs, J.R., 2012. Cementum annulations, age estimation, and demographic dynamics in Mid-Holocene foragers of North India. HOMO-J. Comp. Hum. Biol. 63, 94-109.

Roffey, S., Tucker, K., 2012. A contextual study of the medieval hospital and cemetery of St Mary Magdalen. Winchester, England. Int. J. Paleopathol. 2, 170-180.

Ruffin, L., Palich, R., Demondion, X., Blondiaux, J., Colard, T., Alduc-Le Bagousse, A., Niel, C., Flipo, R.-M., 2011. X-Rays as a sensitive method for the studies of long bones of leg periosteal lesions in leprosy. In: Supplement to the Paleopathology Newsletter. Presented at the 18th European Meeting of the Paleopathology Association, Vienna, p. 115.

Santos, A.L., Roberts, C.A., 2006. Anatomy of a serial killer: differential diagnosis of tuberculosis based on rib Lesions of adult individuals from the Coimbra identified skeletal collection, Portugal. Am. J. Phys. Anthropol. 230 (1), 38-49.

Seillier, C., 2006. Le cimetière germanique de Vron (Somme): essai de reconstitution historique et sociale. In: Delestre, X., Kazanski, M., Prin, P. (Eds.), De L’âge Du Fer Au Haut Moyen Age. Archéologie Funéraire, Princes et Élites Guerrières, Actes Des Tables Rondes Longroy I et Longroy II, Mémoires de l'AFAM. , pp. 159-168.

Solheim, T., 1990. Dental cementum apposition as an indicator of age. Scand. J. Dent. Res. 98, 510-519. 
Sorrel, É., Dejerine-Sorrel, 1932. Tuberculose osseuse et ostéo-articulaire. Masson et cie.

Spekker, O., Palfi, G., Kozocsay, G., Pósa, A., Bereczki, Z., Molnár, E., 2012. New cases of probable skeletal tuberculosis from the Neolithic period in Hungary-a morphological study. Acta Biol. Szegediensis 56, 115-123.

Stott, G.G., Sis, R.F., Levy, B.M., 1982. Cemental annulation as an age criterion in forensic dentistry. J. Dent. Res. 61, 814-817.

Taylor, G.M., Tucker, K., Butler, R., Pike, A.W.G., Lewis, J., Roffey, S., Marter, P., Lee, O.Y.-C., Wu, H.H.T., Minnikin, D.E., Besra, G.S., Singh, P., Cole, S.T., Stewart, G.R., 2013. Detection and strain typing of ancient Mycobacterium leprae from a medieval leprosy hospital. PLoS ONE 8, e62406.

Tokudome, S., Kono, S., Ikeda, M., Kuratsune, M., Kumamaru, S., 1981. Cancer and other causes of death among leprosy patients. J. Natl. Cancer Inst. 67, 285-289.

Wedel, V.L., 2007. Determination of season at death using dental cementum increment analysis. J. Forensic Sci. 52, 1334-1337.

Wilbur, A.K., Buikstra, J.E., Stojanowski, C.M., 2002. Mycobacterial disease in North America: an epidemiological test of Chaussinand's cross-immunity hypothesis. In: Roberts, C.A., Lewis, M., Manchester, K. (Eds.), Past and Present of Leprosy: Archaeological, Historical, Paleopathological and Clinical Approaches:
Proceedings of the International Congress on the Evolution and Paleoepidemiology of the Infectious Diseases 3 (ICEPID), University of Bradford, 26th-31st July 1999, BAR International Series. Archaeopress, Oxford, pp. 247-258.

Wittwer-Backofen, U., 2012. Age estimation using tooth cementum annulation. In: Bell, L.S. (Ed.), Forensic Microscopy for Skeletal Tissues, Methods in Molecular Biology. Humana Press, New York, NY, pp. 129-143.

Wittwer-Backofen, U., Buckberry, J., Czarnetzki, A., Doppler, S., Grupe, G., Hotz, G. Kemkes, A., Larsen, C.S., Prince, D., Wahl, J., Fabig, A., Weise, S., 2008. Basics in paleodemography: a comparison of age indicators applied to the early medieval skeletal sample of Lauchheim. Am. J. Phys. Anthropol. 137, 384-396.

Wittwer-Backofen, U., Gampe, J., Vaupel, J.W., 2004. Tooth cementum annulation for age estimation: results from a large known-age validation study. Am. J. Phys. Anthropol. 123, 119-129.

Wood, J.W., Holman, D.J., O’Connor, K.A., Ferrel, R.J., 2002. Mortality models for paleodemography. In: Hoppa, R.D., Vaupel, J.W. (Eds.), Paleodemography: Age Distributions from Skeletal Samples, Cambridge Studies in Biological and Evolutionary Anthropology. Cambridge University Press, Cambridge, pp. 129-168. 